\title{
Industrial Geography, Its Meaning, Scope and Content
}

\section{Carl P. Knikk}

To cite this article: Carl P. Knikk (1911) Industrial Geography, Its Meaning, Scope and Content, Journal of Geography, 9:6, 141-146, DOI: 10.1080/00221341108986287

To link to this article: http://dx.doi.org/10.1080/00221341108986287

曲 Published online: 20 May 2008.

Submit your article to this journal

Џ Article views: 5

Q View related articles $\square$ 


\section{THE JOURNAL OF GEOGRAPHY}

\begin{tabular}{llr}
\hline VOL. IX & FEBRUARY 1911 & NO. 6
\end{tabular}

\section{INDUSTRIAL GEOGRAP'HY, ITS MEANING, SCOPE AND CONTENT * \\ By CARL F. KNIRK}

Technical High School. Cleveland, Ohio

$J^{\omega}$ UDGING from the content of the many articles which have recently appeared in the various geographical magazines on "Geography in Secondary Schools," "Secondary School Geography in the Middle West," "The Modern Trend of Geography," etc., there is little to say that is new. However, there may be those who are interested in knowing the results obtained in a school where the oft lamented limitations placed on schools throngh tradition, college requirements, defective texts, laboratory manuals, etc., have been eliminated, and where the course has been shaped according to the best judgment of those in chargc to meet the demand of the patrons of the school and the needs of the pupils.

The patrons frequently feel that the school authorities should be able to give definite reasons why each and every course has a place in the curriculum. The questions, "Why should my son take this subject?", and, "Of what value will it be to him after he leaves school?"; demand the attention of the teacher and those in authority in the school. If, therefore, the teacher of geography insists upon the "tracing of the contours of a map sheet on thin paper, the construction of maps on elaborate nets, the study of several sheets to show the development of cirques, the seeking of mental development in mud-puddle problems, and the extensive study of twelve different kinds of plains from the map sheets, and makes no mention of their human relations," 1 he must show why the boys should do all this work. Or again, if a teacher has a "class that has studied the contour maps in forty different exercises, and on actual quizzing could locate but four of the map sheets studied, could not give the large physical features of the United States and had no conception of the geographic factors which governed the location of their own city." 2 and even though students may be able to "name the town on a purticular map through which a certain contour passes, give the highest and lowest point on each map studied, and plenty of other similar mechanical matter,"3

*An abrigement of a paper read before the Earth Science Section of Central Association of Science and Mathematics Teachers, Cleveland, Nov. 26, 1910.

$1,2,3$ Journal of Geography, January, 1910, pp. 110 to 116. 
yet the teacher must answer the questions, "Why should my son take this subject?" and, "Of what value will it be to him after he leaves school?"

The demand thus placed upon the school was one of the factors which fed the writer and his co-workers to break away from the traditional physical geography or physiography and attempt building a course which should meet this demand.

The needs of the pupils should be a prime consideration in the organization of a course. The geography teacher must decide whether it is of more value for a boy to know the various theories of glacial movement or to know that the Great Central Plain region north of the Ohio and Missouri rivers has.a deeper mantle rock and a more fertile soil because of the former presence of glaciers and consequently has some of the most valuable agricultural land in the world. Shall we spend our time trying to explain to the boys how kames, eskers, drumlins, valley trains, etc., are formed or shall we point out how the glacier decreased the relief in most regions where deposition took place, and hence improved the conditions for agriculture and transportation? Is there not as much interest and keell. straightforward thinking involved in cuntrasting the areas of glacial erosion and glacial deposition as in trying to figure out how many times the glacier retreated and advanced? And will not the boys in after years appreciate the former fully as much as the latter?

The answer to such questions as these led the writer and his co-workers to the conclusion at which the earth science section of the Central Association of Science and Mathematics Teachers arrived a year ago when it recommended that the course of study in secondary school geography should "be modified so as to include a large amount of human geography, that the final goal should be regional geography in some form, that this regional geography should be based on a thorough study of the essential elements of physiography, and should include the most important principles and details of industrial and commercial geography." Arriving at this conclusion, we at once began the construction of a course to meet these needs which we termed Industrial Geography.

\section{A COURSE IN INDUSTRIAL GEOGRAPHY}

The Atmosphere. The work in industrial geography should begin with a study of the gases of the atmosphere. The composition of the air and the uses of the principal gases should be discussed and laboratory experiments to demonstrate the text should be performed. In all this work emphasis should be placed on how the moisture gets into and out of the atmosphere and the influence which it exerts on plant and animal life by modifying the rate of evaporation, the rainfall and the temperature of the earth. In class the student should continually be confronted with the question, "What of it?" This work should be followed by a study 
of the temperature and pressure and the resulting general circulation of the atmosphere about the earth. The students are then prepared to begin the study of weather, introduced by a study of the weather map. In this, the aim is to prepare students to predict weather when certain conditions exist and to be able to explain why such conditions usually bring about certain weather changes. The work on weather naturally leads to a study of the climate of the United States.

Before leaving this phase of the subject it may be well to call attention again to the importance of placing emphasis on human relations to climatic conditions. The boys like to show that, because the northern states are from 30 to 40 degrees colder than the southern states during the winter months, better shelter, warmer clothes, better food and more fuel are needed by the northern inhabitants, that the growing season is shorter; and that the season during which domestic aniwals must be fed and sheltered is much longer; that during a short summer provision must be made for a longer winter; that certain lines of outdonr work must be abandoned during the winter months, and that the return for the summer's labor must be sufficient to carry men through the winter months or that other occupations must be carried on during the winter months. They readily suggest that railway traffic is frequently delayed by snow and ice storms and that traffic on the Great Lakes and other water ways must be suspended during the winter months. A discussion of these topics lends interest to the every day affairs of men and it teaches boys to observe and to think about the conditions under which they and men everywhere live.

The Earth's Crust. The second portion of the work in industrial geography should embrace a study of the more common mantle, sedimentary and igneous rocks. This study should include the origiv, pronounced characteristics and common uses of each. Laboratory specimens and field excursions will add interest and valuable knowledge to this phase of the work. In this connection a few of the more common crustal movements and disturbances may be discussed, forming a basis for the study of the Block Mountains in the Great Basin region, of the earthquakes associated with the Pacific Coast mountains, and the igneous plateau in Oregon and Washington.

The work of water, wind, ice and snow. This portion of the work would not be complete without a study of the work of surface and ground water, of wind, ice and snow. In the study of ground water the influence of geographic conditions on man can be brought out clearly. The interrogation, "Who cares how near to the surface ground water mav be found?" at once brings out the fact that plants are largely dependent on ground water for their food and that they cannot grow when grounci water is not found near the surface. This fact grasped, the thought naturally follows that without plants man is practically helpless, for his food supply is de- 
pendent upon them. The study of ground water naturally leads to a study of surface water or drainage, since the level of the ground water is commonly determined by the drainage. This study should, of course, include the work of streams and the characteristics which mark the various stages of erosion but it should not end there.

Adaptation of industries to physical conditions. If rur study of geography is to give us knowledge which will help us to see how dependent we are on our physical surroundings, we must show how regions with certain characteristics are adapted to certain industries, while regions with other characteristics are adapted to quite different occupations. Thus a region in an immature stage of erosion with its steep slopes, scanty soil and rapid streams has little value for agriculture except in the level portions of the river valleys. The average boy becomes interested when he sees that the forests should be left upon the hill sides to protect not only the uplands but the valleys as well. Every boy is able to advance a number of arguments to sliow that the forests should be left upon the highlands. The schemes by which the mountaineer overcomes some of the difficulties of transportation appeal to boys and they are in sympathy with him when they realize how he is handicapped by his surroundings.

On the contrary, boys are always interested in seeing that mucheroded mountain regions are adapted to mining, because, (1) the rocks of various strata are exposed and it is easy to find the minerals, and (2) strata, which have long been buried and which are therefore likely to have accumulated mineral deposits, are brought near the surface. We, therefore, find mining cities like Pittsburg and Birmingham located in regions where rivers have cut deep gorges in the rock. Grazing, manufacturing, transportation and rarious other industries may be discussed in a like manner.

The study of the work of snow and ice becomes vital when the students understand that many of the industries of today are still influenced by the glaciers of the past. Thus some areas are now barren and practically useless because of glacial action; while other areas are the centers of industry and commerce because of the changes which took place during the Glacial Period. Will not a knowledge that the most valuable agricultural land in this country lies in the glaciated area where the amount of soil and mantle rock has been increased, where the soil is most likely to be fertile, since it contains a great variety of disintegrated rock derived from extensive areas and where the relief has been decreased, afford as much satisfaction to the average high school graduate as a knowledge of how glacial striae and grooves may have been produced? Will not a discussion of the influence of the Glacial Period on agriculture, manufacturing, mining, fishing, and transportation involve as much mental development as a guess as to how long a period of time lapsed between the different glacial advances? 
Regional Geography. The phases of physical geography thus far discussed will give the student a basis for a study of regional geography that is both systematic and causal. The knowledge thus gained from physical geography should find application in a scientific study of regional geography in which the larger life relations are brought out. This regional geography will acquaint the student with the chief physical features of our country and those of the leading nations of western Europe; it will give him an idea of the resources of this country; it will teach him something of the value, distribution, and relation of the various industries; and most of all, it will show him that the life of a nation is dependent on its resources and hence on those industries which employ the great mass of the people.

In regional geography, the units of study may be determined by physiographic features. This seems to be the easiest and most logical basis by which to determine the units of study, since the physical features are thus quite similar and the industries usually have many characteristics in common. Thus a plain is certain to be adapted to agriculture if it has sufficient rainfall, whether it is found in the northern or southern part of the United States, although the crops grown may depend on temperature. The plains in the northern states produce corn, wheat and oats, while those in the southern states yield cotton, rice and tobacco. But in both sections agriculture is the leading occupation.

Having located the physiographic unit to be considered, the climate, the general characteristics of the surface, the drainage and the soil should be studied. This study naturally leads to a consideration of the agricultural and mineral products. Knowing the physical characteristics, the climate, the farm and the mineral products of the area, the students are prepared to discuss the manufacturing industries. The order in which the topics are studied will vary in different sections. Thus, in the New England region the lumbering and fishing industries should be given speeial consideration.

The study of each section should emphasize those industries which yield the greatest returns to the mass of the inhabitants. The study which deals with the New England region is not complete urless it shows why this region has produced large quantities of lumber and why it should continue to be a center of the paper industry.

Again the agriculture of the Upper Mississippi Valley is quite different from that of the Gulf region and hence we have an opportunity to place the emphasis on the conditions which cause certain crops to grow in certain areas and on the methods by which these crops are produced.

The most important manufacturing industries are studied in the same manner. The making of cloth and the manufacture of borits and shoes are taken up in connection with the study of the New England Hills. The influence which water power, nearness of raw material and access to 
a market have on manufacturing is brought out in this connection and later on the influence of these factors is emphasized in the study of the iron and steel industry and its development.

In connection with all of this work it is possible to place emphasis on the causal relations. By doing this we make the work interesting to the student, we help him to associate events with causes, and teach him to look for a reason for all things.

The year's work closes with a study of the most important nations of western Europe. The study of these nations should familiarize the student with the climatic and physiographic conditions of each country studied and it should acquaint him with the leading industries and the methods by which they are carried. on. It should show the student the difference between the intensive methods of western Europe and the extensive methods of this country. And most of all it should point out the needs and demands of these nations so that we may be able to meet them and thus rèalize the greatest returns for our labor.

In conclusion, industrial geography aims to teach those phases of weather, climate and physiography which are deemed essential to a rational understanding of regional geography. It presents regional geography from a physiographic basis and it places emphasis on the causal relations which exist between the physiographic and climatic conditions and resulting industries, and it aims to bring out the larger life relations. It aims to present locational geography through a thorough map study in connection with regional geography; and lastly, it familiarizes the student with the conditions under which he and his fellow men live, and the needs and demands of the important nations with which our country deals.

There is some consolation in finding that American students are not the only ones who show an inexcusable ignorance of locational geography. An examiner of English schools complains of the same ignorance in Great Britain. In the London School World of October, is found a report from which the following is taken:

"In Geography, the examiner states, there are satisfactory signs of more general recognition of the fact that the study of distributions is essential: and that no combination of physics, geology, history, or economics can take its place. Candidates, who gave excellent answers to questions on the cotton-manufacturing district of Lancashire or on towns on the coasts of England, not infrequently gave unmistakable evidence (direct or indirect), in answering the map question, that they had no clear idea of the position in England of the places they had been writing about. The need for much more careful and extended use of maps throughout cannot be too strongly insisted on.". 